\title{
Crime and Routine Activity
}

\author{
Rohana Sham ${ }^{1}$, Norlida Abdul Hamid ${ }^{1}$, \\ Suhana Mohamed², Razifah Othman² \\ 1 Faculty of Business and Management, Universiti Teknologi MARA Johor, Malaysia \\ ${ }^{2}$ Faculty of Business and Mangament, Universiti Teknologi MAR, Malaysia \\ rohana320@johor.uitm.edu.my
}

\begin{abstract}
Routine activity and crime are much related to one another. When a women is on their routine trip, the possibility of crime to happen along the routine route is high. Therefore examining the exact routine activities of women travelers is needed by transport operators so that transport services can be offered accordingly to their needs. This paper examine the detail of women routine especially those involve in occupation or working group who are highly depending on public bus to commute. Therefore, the objective of the research is to determine the factors of trip chain, travel distance and time of travelling that affect women's travelling safety issues in an urban area.
\end{abstract}

Keywords: Crime, Working women, Routine Activities, Trip Chain, Quality of Life

eISSN 2398-4279 @ 2018. The Authors. Published for AMER ABRA cE-Bs by e-International Publishing House, Ltd., UK. This is an open access article under the CC BY-NC-ND license (http://creativecommons.org/licenses/bync-nd/4.0/). Peer-review under responsibility of AMER (Association of Malaysian Environment-Behaviour Researchers), ABRA (Association of Behavioural Researchers on Asians) and cE-Bs (Centre for EnvironmentBehaviour Studies), Faculty of Architecture, Planning \& Surveying, Universiti Teknologi MARA, Malaysia.

DOI: https://doi.org/10.21834/ajqol.v3i9.78 


\subsection{Introduction}

The way in which women's travel pattern was studied was using the theory of routine activities being introduced by Cohen (1955) and Felson (1987). Using the theory of routine activities, Cohen and Felson concluded that urban environments and social context affect the relationship between a certain type of activities and certain types of victimizations. However the routine activities theory assumes that regularities or pattern characterize all behaviours, even accident and unexpected occurrences, making them repetitive and predictable. Felson for example noted that the study of crime is a study of accident requiring a general science of surprise. This approach suggests that daily movement and general mobility can either increase or diminish potential victimization and that offending may be deterred, displace or even encourage depending on certain environment and social condition

Based on the safety perception index survey series under the NKRA, the number of respondents who felt safe decreased from 47.5\% in 2011 to 39\% in 2014 (Economic Planning Unit,2014). Due to unknown reason for the decreasing of the safety feeling, women and the characteristics of travelling were investigated.

\subsection{Literature Review}

\subsection{Trip Chain}

Among the identified women travel pattern is the trip chain. According to Spain (1997), trip chain is being considered as a complex travel behaviour, and it is more common for women than men. The statement was agreed by Hamed and Mannering (1993) who found that males were more likely to go direct to home after work than females. They cited the role of females and the activities they pursue (e.g., shopping, personal business and recreation) as reasons for this difference. However, the study fails to fully acknowledge the significance of trip chain on women's level of safety.

To back up the study, Bhat (1997) investigated the differential impact of married and single women on trip chain. He found that married women were more likely to make stops in their commute than married men. The statement was earlier supported by previous researchers (Al-hazily et al. 1994) who indicated that compared to men, women were more likely to trip chain on the way to and from work. However, this phenomenon had not been discussed further towards the safety issues of working women traveling by public bus.

\subsection{Travel Distance}

Another factor of women's travel pattern being identified is the travel distance made by women. All the studies review so far on this attribute suffer from the fact that it fail to consider women's feeling of safe while travelling. However the existing empirical research is unified that women have shorter commuting distance than man (White \& Madden, 1977).

The underlying economic theory presented by White and Madden (1977) suggested that commute length the function of wages, housing prices, income, and other demographic variables with wages and housing prices endogenously determined. Atkin (1989) also believed that given identical education, skill level and income, identical preferences and 
identical household responsibility. For example we would expect men and women to exhibit identical commuting behavior. Specifically the household responsibility hypothesis $(\mathrm{HRH})$ in their finding stated that employed women tend to have greater household responsibility. As a result, they face greater time constraints and ultimately choose shorter commutes than employed men, that is in the context of White's theoretical development.

Madden (1981) further noted that women in most cities generally earned lower incomes and worked shorter hours, so it did not pay to commute long distances. But most of all, they worked closer to home because they need to balance work and household responsibilities, and promptly responded to family emergencies. Finding of the research indicated that there was no relationship between the travel distance and women travel safety. It can be seen in Table 1.

A similar study done by Hanson and Hanson (1981) showed that in the United Kingdom a correlation between the distance travelled by a woman and the need to tend to child care, caring for elderly and domestic responsibilities but not crime. The following Table 1 indicates the distance travelled per person in United Kingdom.

Source: National Travel Survey 1994-96, HMSO, London

Another factor of women's travel pattern being identified is the travel distance made by women. All the studies review so far on this attribute suffer from the fact that it fail to consider women's feeling of safe while travelling. However the existing empirical research is unified that women have shorter commuting distance than man (White \& Madden, 1977).

The underlying economic theory presented by White and Madden (1977) suggested that commute length the function of wages, housing prices, income, and other demographic variables with wages and housing prices endogenously determined. White (1986) also believed that given identical education, skill level and income, identical preferences and identical household responsibility. For example we would expect men and women to exhibit identical commuting behavior. Specifically the household responsibility hypothesis $(\mathrm{HRH})$ in their finding stated that employed women tend to have greater household responsibility. As a result, they face greater time constraints and ultimately choose shorter commutes than employed men, that is in the context of White's theoretical development.

Madden (1981) further noted that women in most cities generally earned lower incomes and worked shorter hours, so it did not pay to commute long distances. But most of all, they worked closer to home because they need to balance work and household responsibilities, and promptly responded to family emergencies. Finding of the research indicated that there was no relationship between the travel distance and women travel safety.

A similar study done by Hanson and Hanson (1981) showed that in the United Kingdom a correlation between the distance travelled by a woman and the need to tend to child care, caring for elderly and domestic responsibilities but not crime. The following Table 1 indicates the distance travelled per person in United Kingdom.

\subsection{Time of Travel}

A considerable amount of literature has been published and researched on time of women's travelling as a factor affecting women's feeling of safe. These studies claimed that women 
faced higher feeling of fear while travelling after dark due to personal safety reason (Hamilton, 2002).

One of the consistent finding on the reason for higher feeling of fear travelling after dark was because of the high crime occurrence during that period of time (Criminal Department Unit, 2012)

An early finding by Pagano and Robert (1972) had indicated that gradually during the decade, riders would shift their use from the evening off peak hours to $9.00 \mathrm{am}$ and $3.00 \mathrm{pm}$ period. Most of the reduction occurred from $3.00 \mathrm{pm}$ to midnight interval was not a coincidental incident. They reported that the decline of a nighttime usage of the public was correlated with both the incidence of serious crime and public perception of unsafe periods.

With this regard, Pearlstein and Wachs (1982) in a study in United States further pointed out that although most crimes on a bus were committed during peak rider ship hours, the rates of occurrence were disproportionately high during the evening that causes high feeling of fear among the passengers.

Another survey such as conducted by Lynch and Atkins (1988) in Southampton stated that the apprehension or fear affected the travel behavior of women. In their study of safety at a bus stop, $16 \%$ of those surveyed felt unsafe by day and $35 \%$ at night. The authors concluded that women would avoid putting themselves into what they considered being vulnerable situations, sometimes forgoing travel all together.

A study on time of crime occurrence in Malaysia conducted by Criminal Department Unit (2012), where the same conclusion was obtained where time of travelling indicated the number of crime occurrence. Statistics from Criminal Department Unit (CDU) reported the following Table 2.

Based on Table 2, most crime happened from 7.00pm-11.00pm. This is a common time for returning from work journey. The second highest time where crime occurred was at around $11 \mathrm{am}-3.00 \mathrm{pm}$ where most of them were going out for lunch. Another critical time where crime occurs on the streets was also when a trip of going to work was concern that is at $7.01 \mathrm{am}-11 \mathrm{am}$. However, the statistics provided by the CDU might have been more attractive if it considered the feeling of safety by women commuters was considered especially when travelling at different time of the day.

Based on all the evidence from the past research, time of women travelling is being considered in this study as the independent variable to be studied.

\subsection{Age}

Previous research finding into examining age and level of fear by Ferraro and LaGrange (1987), articulated that no relationship has been found between age and fear of crime. They argue that 'fear of crime' is not as serious as in the lives of the elderly as portrayed in the literature and media. Their overview of research findings concluded that elderly people as a group was no 'fearful' of crime than those of other ages. They also contended that the 'fear' of older people might not be associated with criminal acts as such but more due to sign of disorder and lack of community control. It is said that being bothered or intimidated by unruly behaviour from young or disorderly people may be contributing more to an older person's expression of a lack of safety than the crime itself and should not be describe as 'fear of 
crime'.

To challenge the view, Evan (1995) had attempted to explain that when it came to age, it was customary to report that the elderly was the most afraid, and for many crimes, this situation was true. However, he then mentioned that when it came to crimes like rape, sexual assault and stranger attacks, the younger women tend to be more fearful. The finding from British Crime Survey in 1994, concluded that older women were likely than other respondent to consider that they would be the victims of such crime. Both of the studies were being supported by Rohana et al. (2012) who claimed that the risk of crime victims differed by age. In their study of women and crime experience, she concluded that although all women were potential victims of rape, sexual assault, gropers, nudging and obscene language, it appeared that some women are more at risk than others. The study also revealed that traditionally young women age between 16 to 24 were most likely to experience rape. Therefore, if no proper security measure was installed to monitor their movement while travelling by public transport especially buses, it was believed that the risk of being the victims was much higher.

Being the least group to be exposed to crime victims, Smith and Torstensson (1997) questioned why "the least victimized by violence was the most fearful of crime (elderly)." They claim this is a "central paradox" in fear of crime literature. The following Table 3 explains in detail on the feeling of safe by women from different age group.

Women age 20-54 years were among the group of people who felt safer travelling by bus during the day with $91 \%$. However when travelling period changed, the total percentage of feeling safe dropped by $50 \%$ which indicated that, at night they felt less safe when travelling by bus was concern. Women age 60 and more felt that travelling at night created less safe period of travelling for them. Only teenagers age 16-19 felt that travelling for them at night was fairly safe with the total of $48 \%$. Overall, all age of women agreed that they felt much safer travelling by bus during the daytime as compared to night trip.

\subsection{Findings and Analysis}

The trend of women travelling pattern to be studied are shown in Table 4 below. Table 4 pointed out the critical aspect of women travelling pattern that potentially affected level of safety. Consistent with the need to travel to work using bus services, the result showed that the majority of the stage bus $(84.7 \%)$ use the bus frequently. The selection of the frequent users as the respondent in this study could be considered as the most crucial aspect as the frequent users were in a truly good situation of describing the real situation they face every day when travelling by bus was concern. In spite of that, Table 5 compares the mean score obtain for level of safety indication travelling during the daytime and after dark for a stage bus service. 
It was apparent from Table 5 that the mean score for travelling during the day and after dark had differences especially in terms of fear level indication. In general, the result indicated that the overall level of fear among current women bus riders was still high especially when travelling after dark was concern.

\subsection{Conclusion}

Many studies have focused on the relationship between transport service characteristics and women personal travel pattern towards travel safety from accident point of view. However, less research devoted to the effect of poor public transport supply and its infrastructure and even fewer have linked poor public transport supply and women personal travel pattern towards crime exposure.

The main contribution of this research is the analysis of the relationship between public transport supply and women personal travel pattern towards the travelling safety issues in an urban area. The evidence from the analysis suggested that factors of time and age of women of women travelling identified as the factors that affect women level of safety for a stage bus users. This evidence suggest that an urgent need to invest and implement the safety policy guide of the public transport services, and it's infrastructure to these urban areas facilities especially when there is an increase in the involvement of women in employment sectors.

Another important results of this investigation revealed that factor of 'age' identified as the most significant factors that affect women's level of safety particularly for a stage bus users. These findings stressed that it is necessary to understand the need of different age group towards a safe travel because elderly women above 40's indicates a higher level of fear over the same quality of the public transport services and infrastructure provided to them. This can be accomplished by identifying the travelling needs of elderly women and ensuring that transport operators meet expected standards and better enforcement through a tighter licensing regulation.

More women travel during off peak hours public transport service to meet their employment purposes, it is essential to ensure that a transport service being offer is safe and perceived as safe to them. Apart from that, it is also crucial to design a policy and guideline that respond to real and perceived safety issues face by women since both have the ability to create a constrain in women's activities. Therefore, public transport planers have a responsibility to ensure that all women using bus services can complete their whole journey (from origin to destination), possibly door-to door, without made to feel unsafe.

\section{Acknowledgement}

Many thanks goes to family and friends as well as the public transport operators and passengers who had participated in this study. 


\section{References}

Al-Kazily, Barnes, G., \& Coontz, F. (1994). Household structure and travel behaviour. Journal of Demographic, 1433, 201-211.

Atkins, S. (1989). Women travel and personal. Transportation Journal, 12(2), 17-45.

Bhatt, K. (1997). Transportation improvement and road pricing: A demonstration program. Journal of Transportation, 408, 339-349.

British Crime Survey, (1994). Anxiety About Crime. Retrieved July ,2012 from http://www.crimeconcern.com

Cohen, L. E. (1955). Delinquent boys: The culture of the gang. Glencoe: Free press.

Criminal Department Unit. (2012). Crime In Malaysia (Report): Royal Malaysia Police Department

Evans, D. J. (1995). Crime and policing: Spatial approach: England: Avebury.

Felson, M. (1987). Routine activities and crime prevention in the developing metropolic criminality: Stanford University Press.

Ferraro, K. F., \& LaGrange, R. (1987). The measurement of fear of crime. Journal of Criminal Justice, 57, 70-101.

Focas, C. (1989). A survey of women's travel needs in London. Journal of Transportation, 12(2), 17-45.

Hamilton, K. (2002). Gender and transport in develop countries: London Press.

Hanson, S., \& Hanson, P. (1981). The impact of married women's employment of household travel pattern: Wall Press.

Lynch, G., \& Atkins, S. (1988). The influence of personal security fears on women's travel pattern. Transportation Research Journal, 15, 257-277.

Madden, F. (1981). Why women work closer to home. Journal of Urban Studies, 18, 181-194.

Pagano, S., \& Robert, T. (1972). Who notice, who cares? Passengers reaction to transit safety measures. Transportation Journal, 2, 131-142.

Pearlstein, A., \& Wachs, M. (1982). Crime in public transit system: An environmental design perspective. Transportation Journal, 11, 277-297.

Rohana,S., Norhayat,O., Dia,W.A.(2012). Hot Spot Crime Area For Women Travellers.Proceeding in 2012 ASEAN Conference on Environment -Behaviour Studies (AcE-Bs 2012),Cairo Egypt 31st Oct-2nd Nov 2012.Elsevier Publication.

Smith, W. R., \& Torstensson, M. (1997). Gender differences in risk perception and neutralizing fear of crime: Towards resolving paradoxes. British journal of criminology. 37(4), 608-634.

Spain, D. (1997). The aging baby boomers and women's increased independence (Report): Department of transportation.

White, J. (1986). Sex differences in urban commuting pattern. The American economic review, 76(2), 368-332. 
Sham, R. et.al. / Asian Journal of Quality of Life (AjQoL), 3(9) Jan / Feb 2018 (p.69-76)

White, J., \& Madden, F. (1977). A model of residential location choices and commuting by men and women. Journal of Regional Science, 17(1), 41-52.

Economic Planning Unit. (2014). Creating Safer Living Space and Secure Environment; Eleventh Malaysia Plan. Prime Minister's Department. Federal Government Administrative Centre, Putrajaya: Malaysia. 